\title{
Dynamics of the Content of Mineral Forms of Nitrogen in the Water of Small Rivers in Khabarovsk during the Winter Period
}

\author{
Vladimir Pavlovich Shesterkin'1, Irina Sergeevna Sinkova', Oleg Igorevich Kaminsky ${ }^{1 *}$ \\ 1 Khabarovsk Federal Research Center of the Far Eastern Branch of the Russian Academy of Sciences, \\ Institute of Water and Ecology problems FEB RAS, 680021, Khabarovsk, Russia \\ *Corresponding author's email: kamin_div0@mail.ru
}

\begin{abstract}
This work is devoted to the study of the content of mineral forms of nitrogen in the water of small rivers in Khabarovsk and its surroundings, represented by the Bolshekhekhtsirsky Nature Reserve, during the winter low water of 2017-2021, which lasts from December to February. The dynamics of quantitative distribution of ammonium, nitrite, and nitrate nitrogen in relation to different groups of watercourses were considered. The correlation analysis enabled to reveal the probable reasons for such correlations of their content.
\end{abstract}

Keywords: water, small rivers, Khabarovsk, pollution, nitrite nitrogen, nitrate nitrogen, ammonium nitrogen

\section{INTRODUCTION}

The problem of water quality of small rivers of large cities is valid for many countries of the world. Compared to large rivers, such watercourses are affected by anthropogenic factors to a much greater extent, because they are characterized by weak self-purification capacity, as well as the strong impact of both point effluent discharges and diffusion sources of pollution. Pollution is most acute in the low-water periods in urban areas with high population density [Wang et al., 2018].

Under the conditions of the Russian Far East, the maximum pollution of small rivers in urbanized areas is mainly observed during the winter low-water period from December to February. At such time, watercourses are mainly fed by groundwater and untreated sewage from housing and communal services, but there is no dilution with atmospheric precipitation. This condition contributes to an increase in the degree of river waters pollution.

Mineral forms of nitrogen (ammonium, nitrite and nitrate) are substances that set the boundaries of quality of nature waters and determine the biological productivity of water bodies.
The nitrification and denitrification processes are invariably affected by the discharge of large amounts of nitrogen compounds and organic substances by humans. Thus, its activities have a significant impact on the natural nitrogen cycle in nature [Hayatsu et al., 2008].

The city of Khabarovsk, founded in 1858 , is the administrative center of the Khabarovsk region, it is located on the right bank of the Amurskaya Channel and the Amur River on an area of $386 \mathrm{~km} 2$, near the border with the PRC. Until 2018, Khabarovsk was the administrative center of the Far Eastern Federal District. The population currently stands at 610.3 thousand people.

The problems of the quality of small rivers in Khabarovsk have existed for more than a century. The information about the water pollution in the Plusninka, Cherdymovka, and Lesopilka rivers, tributaries of the Amur River, was mentioned in scientific literature in 1905 [Chirikov, 1905]. The observations in 1913 testified about the pollution of waters of the Plusninka and Cherdymovka rivers by ammonium and nitrite nitrogen [Ebergard et al., 1914].

Further expansion of the city affected the catchments of the Chernaya, Berezovaya, Osipovka, Polezhaevka and other rivers; after 1957, the 
beds of the Plusninka, Cherdymovka and Lesopilka were removed into concrete collectors.

Rare microbiological [Fisher et al,, 2018] and hydrochemical observations on small rivers in 2017-2018 revealed water pollution by organic matter, ammonium and nitrite nitrogen, and phosphates [Shesterkin et al., 2019; Shesterkin et al., 2021].

Studies in subsequent years (2019-2021) [Sinkova, 2021] allowed conducting a more detailed study of the dynamics of the content of mineral forms of nitrogen in the water of small rivers in Khabarovsk during winter low water, i.e. the most difficult period for watercourses, when the impact of human activity is most noticeable.

\section{OBJECTS AND METHODS}

Hydrochemical studies were carried out during the winter periods, monthly from December 2017 to February 2021 in the central part of Khabarovsk and its environs, episodically also in the Bolshekhetsirsky State Reserve, located $15 \mathrm{~km}$ from the city.
A schematic of the study area is shown in Figure 1. The water samples were taken from the surface in the middle of the rivers. The analyses were carried out at the Center of Collective Use at the Institute of Water and Ecological Problems of the Far East Branch of the Russian Academy of Sciences according to the methods generally accepted in hydrochemical studies. The $\mathrm{pH}$ values, nitrite, nitrate and ammonium nitrogen content were determined. A SHIMADZU UVmini-1240 spectrophotometer and a METTLER TOLEDO S47 SevenMulti $\mathrm{pH} /$ conductometer were used as the measuring equipment.

\section{RESEARCH RESULTS}

The chemical composition of waters of the small rivers of Khabarovsk and its suburbs is formed in The Amur-Sungarian Plain, bounded in the north by the Voronezh Heights and in the south by the foothills of the Big and Little Khekhtsir. In the winter period, the rivers are fed mainly by underground waters of Voronezh (northern and central part of the city) and hydrogeological massifs of the Little Khekhtsir (southern part)

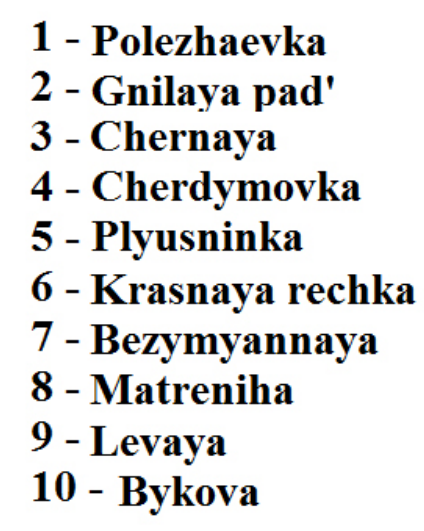

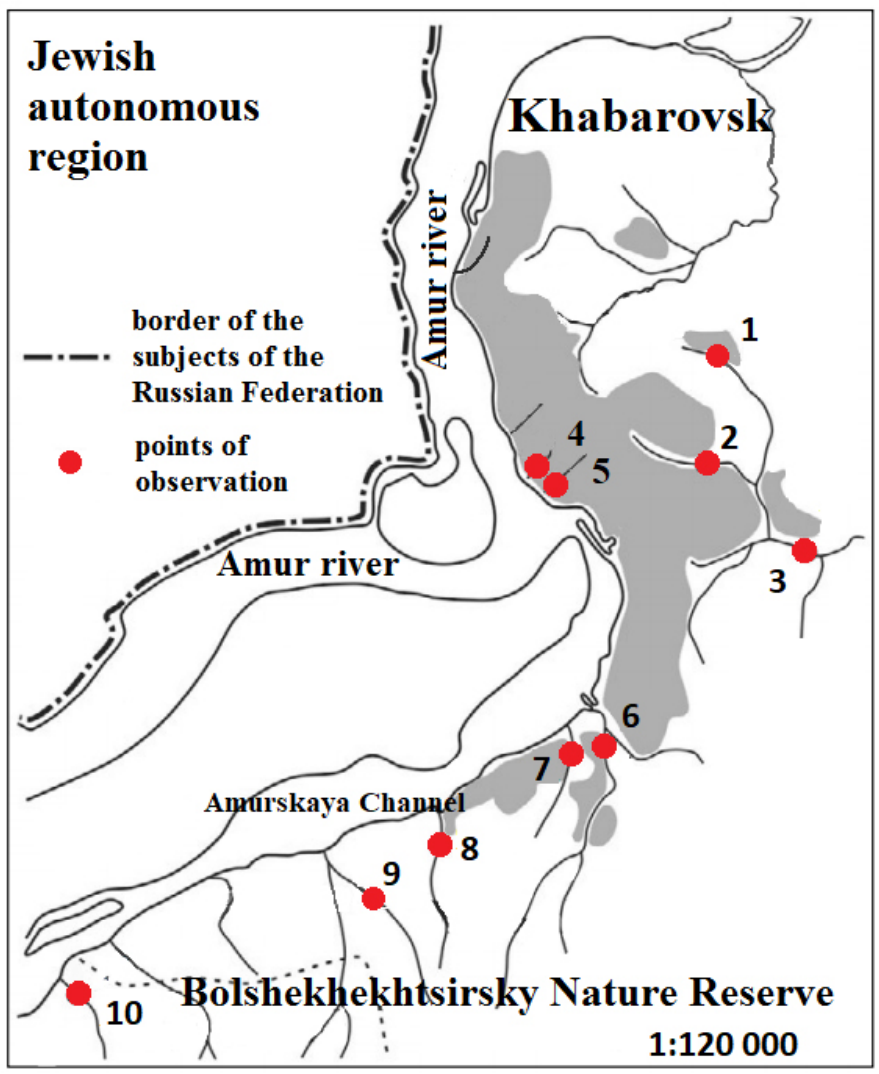

Figure 1. Scheme of the location of watercourses in Khabarovsk 
and Khabarovsk artesian basin (eastern part). The waters of these hydrologic massifs are mixed hydrocarbonate with salinity of $50-200 \mathrm{mg} / 1$ [Averyanova et al., 1998]. An important source of feeding the rivers of the central part of the city is the waters of the water supply and drainage systems due to their wear and tear.

Rivers drainage the territory of the Bolshekhekhtsirsky Reserve are not influenced by the economic activities in the catchment area. Such natural conditions of natural processes result in very low concentrations of ammonium and nitrite nitrogen $(<0.08$ and $0.014 \mathrm{mg} / \mathrm{l}$, respectively) and elevated concentrations of nitrate nitrogen (up to $3.84 \mathrm{mg} / \mathrm{l}$ ) [Shesterkin et al., 2019]. The given indicators are taken as background values for the territory under consideration.

Since small rivers in the central part of the city (Cherdymovka, Plusninka) are sheltered in concrete collectors, and are fed by the warm water from worn-out water supply and sewage systems, their estuaries are not covered by ice even in the most severe frosts.

Having compared these two rivers with each other, it was noted that the Cherdymovka River, which drains an area partially occupied by lowrise buildings, is characterized by a wide variation in concentrations of mineral forms of nitrogen (Fig. 2a,b). Among them, ammonium ion dominates in most cases. Its maximum content (7.41 mg/l) was observed in December 2017 and its minimum $(1.47 \mathrm{mg} / \mathrm{l})$ in February 2019. (Fig. 2a). Within a narrower range of 0.89 to $5.20 \mathrm{mg} / 1$ (Fig. 2b), ammonium nitrogen content varied in the water of the Plusninka River, which drains the city area with high-rise structures. Among both rivers, the nitrite nitrogen content did not exceed $0.93 \mathrm{mg} / \mathrm{l}$, and the nitrate nitrogen content was $9 \mathrm{mg} / \mathrm{l}$ (2020). A wide range of diffusive sources of pollution and episodic influx of sewage into the river network lead to large differences in concentrations of mineral forms of nitrogen. Under such conditions, there are no certain regularities in their content during winter, and maximum values can be observed in any month.

The rivers in the rest of Khabarovsk are not covered by collectors and are often blocked by ice. This phenomenon is mostly observed in the rivers drain the territory of the private sector and garden plots. In particular, small rivers on the northern and southeastern outskirts of the city (Polezhaevka, Krasnaya Rechka), fed by groundwater from alluvial deposits, freeze to the bottom in harsh winters (2019-2020). These streams are characterized by high levels of nitrate nitrogen (Fig. 3c), in relation to the amount of ammonium nitrogen, exceeding most of the indicators of other rivers of the city. The studies conducted in the winter low-water years, i.e. 2020-2021, show a sharp increase in the nitrite nitrogen (Fig. 3b).

The main source of feeding of small rivers in the southern and northeastern outskirts of the city (Matrenikha, Gnilaya Pad, Chernaya, Bezymyannaya) is untreated wastewater, which contributes to the fact that rivers are covered with ice only in the most severe frosts (2019-2020). The predominance of ammonia nitrogen (up to $54 \mathrm{mg} / \mathrm{l}$ in the Bezymyannaya River) and low content of oxide forms of nitrogen are noted as characteristic features (Fig. 3).

Considering Figures 2 and 3 together, it was concluded that the content of ammonium nitrogen in different years is not stable, and relative to the background value $(0.08 \mathrm{mg} / \mathrm{l})$ is higher. Moreover, exceeding the background value $(0.014 \mathrm{mg} / \mathrm{l})$ was noted for the nitrite nitrogen content, the maximum value of which was recorded in the waters of the rivers which drains the central part of the
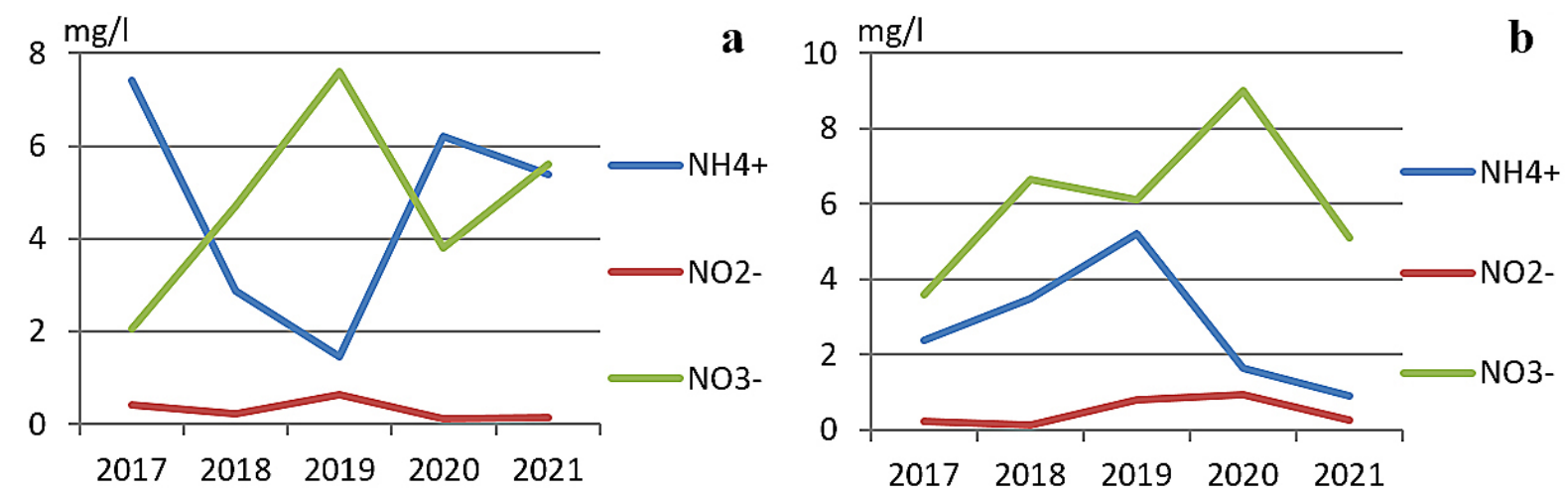

Figure 2. $\mathrm{NH}_{4}^{+}, \mathrm{NO}_{2}^{-}, \mathrm{NO}_{3}^{-}$content in the rivers: a) Cherdymovka; b) Plusninka 
city. The graph of the nitrate nitrogen content in the water of rivers stands out most clearly, as exceedances of the background value $(3.84 \mathrm{mg} / \mathrm{l})$ are observed to a lesser extent. Only the waters of the Polegaevka, Krasnaya Rechka, Plusninka and Cherdymovka rivers steadily contain more of it (Fig. 3c).

A correlation analysis was carried out to arrange the values of concentrations of mineral forms of nitrogen in the water of small rivers of Khabarovsk. The calculated coefficients are presented in Table 1. By correlating them with the standard scheme of oxidation of nitrogen compounds in river water, a number of assumptions were made to interpret the data obtained in the hydrochemical studies

The clear lack of correlation between $\mathrm{NH} 4+$ and $\mathrm{NO}_{2}^{-}(\mathrm{k}=0.01)$ probably indicates an extremely weak activity of the oxidation process of $\mathrm{NH}_{4}^{+}$to $\mathrm{NO}_{2}^{-}$. This disruption of the nitrogen cycle is associated with a lack of free oxygen, which is required for the vital activity of ammonia-oxidizing bacteria involved in the nitrification process [Wang et al., 2021], [Soliman et al., 2018]. This is due to the formation of thick ice cover on small rivers in Khabarovsk, which are not covered by concrete collectors.

The effect of oxygen deficiency on the suppression of nitrite-oxidizing bacteria can also be traced (Wang et al., 2021). This is demonstrated by the extremely weak activity of the oxidation process of nitrite nitrogen to nitrate nitrogen, and the lack of correlation between $\mathrm{NO}_{2}^{-}$and $\mathrm{NO}_{3}^{-}$ $(\mathrm{k}=0.16)$ confirms this.

The result of impaired nitrification in water is the observed overabundance of ammonium nitrogen, due to the impossibility of its oxidation to $\mathrm{NO}_{3}^{-}$. This is indicated by the negative correlation coefficient $(\mathrm{k}=-0.65)$ between $\mathrm{NH}_{4}^{+}$and $\mathrm{NO}_{3}^{-}$.

It should be emphasized that the described disturbances affect the denitrification process [Coskun et al., 2017], as a result of which nitrogen
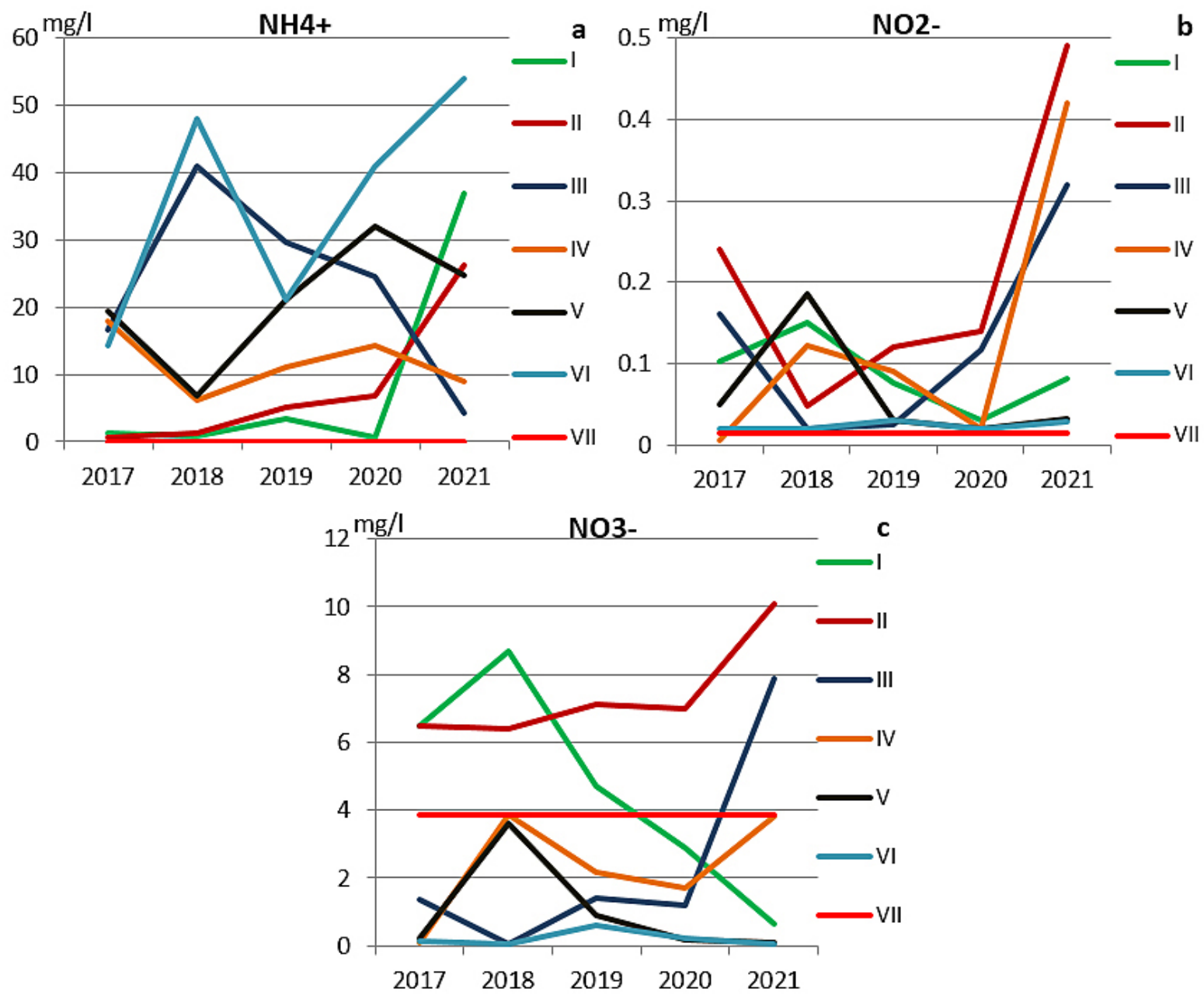

Figure 3. Contents in the rivers (I) Polezhaevka, (II) Krasnaya Rechka, (III) Matrenikha, (IV) Gnilaya Pad, (V) Chernaya, (VI) Bezymyannaya, (VII) reserved areas: a) $\mathrm{NH}_{4}^{+}$; b) $\mathrm{NO}_{2}^{-}$; c) $\mathrm{NO}_{3}^{-}$ 
Table 1. Correlation matrix of $\mathrm{NH}_{4}^{+}, \mathrm{NO}_{2}^{-}, \mathrm{NO}_{3}^{-}$ content in waters of small rivers of Khabarovsk in winter 2017-2021

\begin{tabular}{|l|c|c|c|}
\hline Compound & $\mathrm{NH}_{4}^{+}$ & $\mathrm{NO}_{2}{ }^{-}$ & $\mathrm{NO}_{3}{ }^{-}$ \\
\hline $\mathrm{NH}_{4}{ }^{+}$ & 1.00 & - & - \\
\hline $\mathrm{NO}_{2}^{-}$ & 0.01 & 1.00 & - \\
\hline $\mathrm{NO}_{3}^{-}$ & -0.65 & 0.16 & 1.00 \\
\hline
\end{tabular}

reduction from oxidized forms occurs in smaller volumes. Low water temperatures also have a negative effect on the rate of reactions [Kallistova et al., 2016].

Considering the conditions of free oxygen deficit in water, it should be noted that the oxidation of ammonium nitrogen is possible by the anammox process [Kallistova et al., 2016]. Such an oxidation process is usually not limited by the level of ammonium, which is usually rather high in natural water systems, but strongly depends on the availability of the electron acceptor, nitrite [Broda, 1977]. The hydrochemical studies presented in this work showed that the amount of ammonia nitrogen in the water of small rivers of Khabarovsk is much higher than the level of nitrite nitrogen. The lack of nitrite combined with low environmental temperatures reduces the possibility of oxidation of ammonium by anammox.

Sulfate-dependent anammox, the course of which is described by the following reaction, can serve as an analogue of such a process: $2 \mathrm{NH}_{4}^{+}+$ $\mathrm{SO}_{4}{ }^{2-} \rightarrow \mathrm{N}_{2}+2 \mathrm{H}_{2} \mathrm{O}$. In the case of the rivers in question, this oxidation pathway is not possible because the $\mathrm{pH}$ is in the range 6.2-7.6, and the sulfate-dependent anammox process requires a $\mathrm{pH}>$ 8.0 for it to proceed effectively [Liu et al., 2008].

\section{CONCLUSIONS}

Thus, the presence of a wide range of unregulated sources of watercourse feeding does not allow identifying certain regularities in the differences in the content of mineral forms of nitrogen in the waters of small rivers of Khabarovsk over time. Episodic inflow of wastewater can provoke strong increases in concentrations of the substances determined in any month of the winter low water.

Compared with the accepted background content for the area under study, the studied waters are heavily polluted with ammonium and nitrite nitrogen with a multiple excess of their content in 675 and 92 times, respectively.
The waters of the rivers in the southern and northeastern outskirts of the city, which drain areas with low-rise buildings, and the main source of supply are untreated sewage from housing and communal services are the most contaminated with ammonia nitrogen. The rivers of the central part of the city, which are fed mainly by waters of worn-out sewage and water supply systems, are characterized by an increased content of ammonia nitrogen and significant pollution by nitrite nitrogen, which is 66.4 times higher than the accepted background value.

\section{Acknowledgements}

The authors would like to thank the Collective Use Center at the Institute of Water and Ecological Problems of the Far East Branch of the Russian Academy of Sciences for the equipment provided for the research.

\section{REFERENCES}

1. Averyanova L.P., Goreiko D.L., Kulakov V.V. 1998. Khabarovsk underground waters and their pollution. Khabarovsk: as it is today (ecological condition), 115-118.

2. Broda E. 1977. Two kinds of lithotrophs missing in nature. Zeitschrift für Allgemeine Mikrobiologie, 17, 491-493. DOI: 10.1002/jobm.19770170611

3. Chirikov A.V. 1905. Rivers of the Amur basin (Shilka, Amur and Sungari) in sanitary terms, 133.

4. Ebergard A.I., Belokhvostov S.I. 1914. Water in the central part of Khabarovsk (in summer). Materials on the study of the Amur Krai: Proceedings of the 1st Congress of Doctors of the Amur Krai. Khabarovsk, 125-134.

5. Coskun D., Britto D.T., Shi W., Kronzucker H.J. 2017. Nitrogen transformations in modern agriculture and the role of biological nitrification inhibition. Native Plants, 3, 17074. DOI: 10.1038/ nplants.2017.74

6. Fisher N.K., Garetova L.A., Imranova E.L., Kirienko O.A., Afanasyeva M.I. 2018. Environmental assessment of small rivers in the central part of Khabarovsk in the period of snowmelt. Regional Problems, 21(3), 35-44. DOI: 10.31433/1605-220X-2018-21-3-35-44

7. Hayatsu M., Tago K., Saito M. 2008. Various players in the nitrogen cycle: diversity and functions of the microorganisms involved in nitrification and denitrification. Soil Science and Plant Nutrition, 54, 33-45. DOI: 10.1111/j.1747-0765.2007.00195.x 
8. Kallistova A.Yu., Dorofeev A.G., Nikolaev Yu.A., Kozlov M.N., Kevbrina M.V., Pimenov N.V. 2016. Role of Anammox Bacteria in Removal of Nitrogen Compounds from Wastewater, Microbiology, 85(2), 140-156. DOI: 10.1134/S0026261716020089

9. Liu S., Yang F., Gong Z., Meng F., Chen H., Xue Y., Furukawa K. 2008. Application of anaerobic ammonium-oxidizing consortium to achieve completely autotrophic ammonium and sulfate removal. Bioresource Technology, 99, 6817-6825. DOI: 10.1016/j. biortech.2008.01.054

10. Shesterkin V.P., Afanas'eva M.I., Shesterkina N.M. 2019. Features of the water quality in small rivers of Khabarovsk in winter season. Geoeclogy. Engineering geology, hydrogeology, geocryology, 3, 42-51. DOI: $10.31857 /$ S0869-78092019342-51.

11. Shesterkin V.P., Sinkova I.S., Shesterkina N.M. 2021. Phosphates in the water of small rivers of Khabarovsk in winter low water. Geosystems of Northeast Asia: nature, population, farm of the territories, 145-148. DOI: 10.35735/tig.2021.54.97.025
12. Sinkova I.S. 2021. Assessment of water quality in small rivers of Khabarovsk during the winter lowwater period of 2020-2021. Regional Problems, 24(2-3), 43-46. DOI: $10.31433 / 2618-9593-2$ 021-24-2-3-43-46

13. Soliman M. \& Eldyasti A. 2018. Ammonia-Oxidizing Bacteria (AOB): opportunities and applications-a review. Reviews in Environmental Science and Bio/Technology, 17, 285-321. DOI: 10.1007/ s11157-018-9463-4

14. Wang L., Zhang J., Li H., Yang H., Peng C., Peng Z., Lu L. 2018. Shift in the microbial community composition of surface water and sediment along an urban river. Science of The Total Environment, 627, 600-612. DOI: 10.1016/j.scitotenv.2018.01.203

15. Wang N., Gao J., Liu Y., Wang Q., Zhuang X., Zhuang G. 2021. Realizing the role of N-acylhomoserine lactone-mediated quorum sensing in nitrification and denitrification: A review. Chemosphere, 274, 129970. DOI: 10.1016/j. chemosphere.2021.129970 